\title{
The effects of dried pistachio epicarp on lambs' performance
}

\author{
A Mahdavi ${ }^{1}$, M Zaghari ${ }^{2}$, M Zahedifar ${ }^{1}$, A Nikkhah ${ }^{2}$, F Alemi $^{3}$, A Hosseini $^{1}$, Z Mirabdolbaghi $^{1}$, H Lotfolahiyan $^{1}$
}

${ }^{1}$ Animal Science Researches Institute of Iran, Karaj, Tehran, Islamic Republic of Iran, ${ }^{2}$ Tehran University, Karaj, Tehran, Islamic Republic of Iran, ${ }^{3}$ Iranian Research Organization for Science and Technology, Tehran, Tehran, Islamic Republic of Iran

Email:mahdavi@asri.ir

Introduction Pistachio by-product or the residue of pistachio after peeling has potentially high nutritive value but its biological effects in ruminants have not been studied extensively. There is about 430000 hectares of pistachio garden in Iran and annual wet and dry pistachio production is 755400 and 253000 tones respectively. This by-product contains: $\% 64.5$ epicarp, \%25 cluster, \%10 leaf and \%0.5 nut and shell. Problems with this by-product are including: 1 -deterioration in less than 24 hours so it could not stored for long term. 2-Pistachio epicarp contains high level of tannins and other phenolic compounds. 3- This by-product is potentially an environmental pollutant and cost effective for disposal. Introducing of pistachio epicarp as feedstuff was the aim of this project.

Materials and methods This experiment was carried out using 70 male lambs with initial weight of $35.9 \pm 1.21 \mathrm{Kg}$ in a completely randomized design Seven groups of ten male lambs were fed for 90 days, iso-caloric, iso-nitrogenous diets, containing either no added pistachio epicarp (control) and added levels 10, 15, 20, 25, 30 and 35 percentage pistachio epicarp in rations. After 90 days feeding, the lambs were slaughtered. Kidneys and livers were fixed in formalin and used for histology and pathology tests. The right half of each carcass was separated into six primal cuts: neck, shoulder, breast, leg, loin and rump. Each cut was dissected into components of lean meat plus bone, fat and residue, which were weighted and calculated as percentage of the whole cut. Data were analyzed with SAS software in proc ANOVA.

Results Inclusion of 10 percent of pistachio epicarp in ration showed a better performance compared to other experimental groups. Inclusion of pistachio epicarp up to 25 percent of ration did not affect final body condition score, total dry matter intake, total gain, feed conversion ratio, final weight and average daily gain. Inclusion of 30 and 35 percentage pistachio epicarp in the ration (treatment 6,7) negatively affected performance of animals. No significant differences were found in weight of stomach and intestine to body weight which indicates that all groups of animals had the same capacity of digestive tract. Measurement of feed intake, showed a high tendency to feed intake in treatment two (10\%). Microscopic and macroscopic pathology of kidneys and livers did not show any damage in all treatments. Except for group two, no significant changes in neck, rump and legs percentage (to cold carcass), were found between experimental groups. Use of pistachio epicarp did not affect the percentage of shoulder. An exception was observed in group seven (35\% pistachio epicarp) which breast and loin were different with other six treatments. The percentages of lean meat plus bone were not different among all groups except for treatments two and seven. The aforementioned result was observed fat. The lowest percentage of fat was observed in group 7 and the highest was belonged to group two.

Table 1 Mean and standard deviation of feed intake, feed conversion, gain, initial and final weight and body condition score

\begin{tabular}{|c|c|c|c|c|c|c|c|}
\hline \multirow[b]{3}{*}{ Total Intake(kg) } & \multicolumn{7}{|c|}{ Rations } \\
\hline & $1(0 \%)$ & $2(10 \%)$ & $3(15 \%)$ & $4(20 \%)$ & $5(25 \%)$ & $6(30 \%)$ & $7(35 \%)$ \\
\hline & $183.63 \pm 3.75^{\mathrm{b}}$ & $197.71 \pm 5.81^{\mathrm{a}}$ & $182.30 \pm 4.36^{\mathrm{b}}$ & $180.28 \pm 3.95^{\mathrm{bc}}$ & $180.18 \pm 5.19^{\mathrm{bc}}$ & $177.51 \pm 2.48^{\mathrm{c}}$ & $168.24 \pm 5.36^{\mathrm{d}}$ \\
\hline FCR & $8.56 \pm 0.063^{\mathrm{b}}$ & $8.23 \pm 0.043^{\mathrm{a}}$ & $8.60 \pm 0.064^{b}$ & $8.54 \pm 0.049^{\mathrm{b}}$ & $8.60 \pm 0.072^{\mathrm{b}}$ & $9.18 \pm 0.001^{\mathrm{c}}$ & $9.32 \pm 0.059^{c}$ \\
\hline Total Gain $(\mathrm{Kg})$ & $21.45 \pm 0.50^{\mathrm{b}}$ & $24.02 \pm 0.73^{\mathrm{a}}$ & $21.19 \pm 0.52^{\mathrm{b}}$ & $21.10 \pm 0.43^{\mathrm{b}}$ & $20.97 \pm 0.64^{\mathrm{b}}$ & $19.34 \pm 0.17^{\mathrm{c}}$ & $18.23 \pm 0.60^{\mathrm{d}}$ \\
\hline $\mathrm{ADG}(\mathrm{gr})$ & $238.32 \pm 5.53^{\mathrm{b}}$ & $266.87 \pm 8.08^{\mathrm{a}}$ & $235.42 \pm 5.78^{b}$ & $234.45 \pm 4.73^{\mathrm{b}}$ & $232.94 \pm 7.14^{\mathrm{b}}$ & $214.90 \pm 1.90^{\mathrm{c}}$ & $202.58 \pm 6.65^{\mathrm{d}}$ \\
\hline IW (Kg) & $35.30 \pm 1.06^{\mathrm{a}}$ & $35.85 \pm 0.71^{\mathrm{a}}$ & $35.00 \pm 1.45^{\mathrm{a}}$ & $35.75 \pm 1.32^{\mathrm{a}}$ & $35.00 \pm 1.15^{\mathrm{a}}$ & $35.05 \pm 1.50^{\mathrm{a}}$ & $35.05 \pm 1.17^{\mathrm{a}}$ \\
\hline FW (Kg) & $56.75 \pm 1.22^{\mathrm{b}}$ & $59.87 \pm 1.21^{\mathrm{a}}$ & $56.19 \pm 1.84^{b}$ & $56.85 \pm 1.18^{\mathrm{b}}$ & $55.97 \pm 1.27^{\mathrm{b}}$ & $54.39 \pm 1.42^{c}$ & $53.28 \pm 1.39^{c}$ \\
\hline Final BCS & $3.45 \pm 0.23^{\mathrm{a}}$ & $3.55 \pm 0.33^{\mathrm{a}}$ & $3.45 \pm 0.23^{\mathrm{a}}$ & $3.53 \pm 0.34^{\mathrm{a}}$ & $3.47 \pm 0.42^{\mathrm{a}}$ & $3.45 \pm 0.37^{\mathrm{a}}$ & $3.48 \pm 0.36^{\mathrm{a}}$ \\
\hline
\end{tabular}

$\mathrm{ADG}=$ Average Daily Gain(gr) $-\mathrm{BCS}=$ Body Condition Score- IW and $\mathrm{FW}=$ initial and final weight- $\mathrm{FCR}=$ feed conversion ratio

Numbers in a row with different letters ( $\mathrm{a}, \mathrm{b}$ and etc) differ significantly $(P<0.05)$.

Conclusions High tendency to feed intake and better performance in treatment two (10\%) may have three reasons: 1Increasing level of pistachio in the diet increased level of phenolic compounds in the ration. Negative effect of tanning on feed intake has well been documented. In treatment $2(10 \%)$ the level of phenolics was not high enough to affect feed intake but at the mean time animals may had been encouraged to more intake due to better taste. 2- All rations were tested in an Gas-Test experiment and the gas production curve showed a positive synergistic effect on dry matter and organic matter digestibility (plus we did another degradation in vitro test by using Tilley and Terry method and that's results showed high digestibility in diet two. 3- As tannins could binding to feedstuffs protein and by-pass them to intestine, a low level of tannin like treatment two can supply an approximate by-pass protein for animals but the higher levels of tannin results to high amount of UDP and low amount of RDP in animals. It could be suggested that the feeding pistachio epicarp up to $25 \%$ of total dry matter intake had no negative effects on performance, carcass characteristics, meat quality and health of lambs. This by-product could be used up to $25 \%$, without negative effect on performance and animal health.

\section{References}

Church, D.C. 1988. The ruminant animal digestive physiology and nutrition. Pentice Hall, New Jersey. U.S.A, 146.

Colomber-Rockers, F., Kirton, A.H., Mercer, G.J.K., Duganzich, D.M., 1992. Small Ruminant Research 7, $161-173$. 